\title{
Editorial \\ Crops: Bringing Together a Global Community of Crop Scientists
}

\author{
Kenneth J. Moore
}

Citation: Moore, K.J. Crops: Bringing

Together a Global Community

of Crop Scientists. Crops 2021, 1, 1-2.

https://doi.org/10.3390/crops1010001

Received: 15 January 2021

Accepted: 15 January 2021

Published: 1 February 2021

Publisher's Note: MDPI stays neutral with regard to jurisdictional claims in published maps and institutional affiliations.
Department of Agronomy, Iowa State University, Ames, IA 50011, USA; kjmoore@iastate.edu

The science behind plants that are grown as crops is essential for confronting many of humankind's existential challenges. The need to feed an ever-increasing human population will require substantial improvements in crop productivity. In the first decade of this century Norman Borlaug predicted that we will "need to nearly double current crop production" by its end to meet projected demand [1]. At the same time population is growing and the demand for food and other plant-based products is increasing at exponential rates, new arable land for crop production is limited. Meeting this challenge of feeding the world will thus require more intensive production from land that is already under environmental pressures from being intensively managed. To be sustainable, crops in the future will need to be grown in ways that protect the natural resources we depend on for their production [2]. It is incumbent upon this generation of crop scientists to develop novel approaches to protecting land, soil and water quality while continuing to enhance crop productivity. This dilemma, producing more food while conserving natural resources, is further exacerbated by a climate changing at an unprecedented rate [3]. The crops and the systems we use to produce them must be made resilient to climate change and the extreme weather events that it has wrought. Never has the work we do as crop scientists been more important than it is today.

These challenges will require a global effort to overcome. Crop scientists working throughout the world are essential to solving them. This journal is designed to break down barriers to communication in this important endeavor. We intend to publish the best crop science from throughout the world. We intend to bring together the many disciplines involved in crop sciences, from molecular biology to ecosystem science and everything in between (For a complete listing of topics appropriate for publication in Crops please see the Aims and Scope of the journal at: https://www.mdpi.com/journal/crops/about.). We intend to publish original articles about all plants that are grown as crops including grains, oilseeds, forages, vegetables, fruits, nuts, and those grown for industrial uses.

For science to be beneficial it must be communicated to everyone. Every article published in Crops will be immediately available worldwide with free and unlimited access to everyone. If you want your work to reach a global audience of crop scientists consider submitting it to Crops, the international journal of crop science.

Conflicts of Interest: The author declares no conflict of interest. 


\section{References}

1. Tuberosa, R.; Phillips, R.L.; Gale, M. In the Wake of the Double Helix: From the Green Revolution to the Gene Revolution. In Proceedings of the International Congress, Bologna, Italy, 27-31 May 2003; pp. 3-23.

2. Al-Kaisi, M.M.; Lal, R. Aligning science and policy of regenerative agriculture. Soil Sci. Soc. Am. J. 2021, 1-13. [CrossRef]

3. Petersen, L.K. Impact of Climate Change on Twenty-First Century Crop Yields in the U.S. Climate 2019, 7, 40. [CrossRef]

\section{Short Biography of Author}

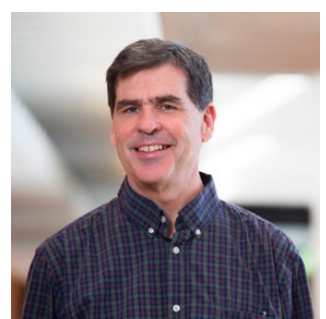

Kenneth J. Moore is Charles F. Curtiss Distinguished Professor in Agriculture and Life Sciences at Iowa State University. Dr. Moore has served as President of the Crop Science Society of America (CSSA) and President of the American Society of Agronomy (ASA). He is a Fellow of ASA, CSSA, and the American Association for the Advancement of Science (AAAS). https:/ / faculty.sites.iastate. edu/kjmoore/ 